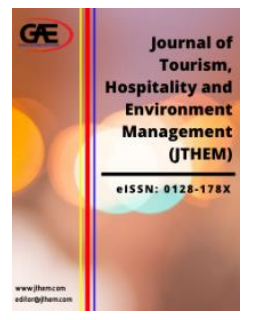

Journal of Tourism, Hospitality and Environment Management (JTHEM)

Journal Website: http://jthem.com/ eISSN: 0128-178X

\title{
THE POTENTIAL OF "KANCRA BODAS FISH" OR "GOD- FISH" LEGEND IN CIBULAN KUNINGAN WEST JAVA INDONESIA AS SUSTAINABLE TOURISM DEVELOPMENT STRATEGIES
}

\author{
Elvi Citraresmana ${ }^{1}$, Wahya $^{2}$, Fatimah Djajasudarma ${ }^{3}$ \\ 1 Department of Linguistics, Faculty of Cultural Sciences, Universitas Padjadjaran \\ Email: elvi.citraresmana@unpad.ac.id \\ 2 Department of Linguistics, Faculty of Cultural Sciences, Universitas Padjadjaran \\ Email: wahya@unpad.ac.id \\ 3 Department of Linguistics, Faculty of Cultural Sciences, Universitas Padjadjaran \\ Email: fatimah.djajasudarma@unpad.ac.id
}

\section{Article Info:}

\section{Article history:}

Received date: 15.12 .2019

Revised date: 14.01 .2020

Accepted date: 24.02 .2020

Published date: 15.03 .2020

\section{To cite this document:}

Citraresmana, E., Wahya., \& Djajasudarma, F. (2020). The Potential of "Kancra Bodas Fsih" or

"God Fish" Legend in Cibulan Kuningan West Java Indonesia as Sustainable Tourism Development Strategies. Journal of Tourism, Hospitality and Environment Management, 5 (18), 67-77.

DOI: $10.35631 /$ JTHEM.518006.

\begin{abstract}
:
This article is aimed at describing how the legend of Kancra Bodas fish or Godfish could raise sustainable tourism development strategies. This research is under the theory of tourism such as the theory of Concept of Sustainability, the theory of Sustainability in Tourism and the theory under the literary study, folklore, and legend. The study conducted by interviewing the custodian of graveyards, the District Government, and Education and Cultural Service in Kuningan. Through the legendary story, there are four important factors which will be beneficial for Cibulan tourist destination, that is the increasing numbers of visitors, maintaining the existence of God-fish, teach the younger or next generation and visitors to learn and practice the local wisdom into their daily lives and also pass down this story legend to the next generation so this story legend still persists in the society whether inside or outside Kuningan society. The study results show that Cibulan through the legend of Kancra Bodas fish has a potential one of sustainable tourism development strategies that should be pertained and promoted by the District Government and also the local people.
\end{abstract}

Keywords:

God-Fish, Prabu Siliwangi, Sustainable, Tourism, Strategies 


\section{Introduction}

Indonesia has many tourist destinations whether offering culinary, scenery, or culture trip; however, if we search for the tourist destination in Indonesia as the keywords, there are listed only 15 the most beautiful places to visit in Indonesia as culture trip see

https://theculturetrip.com > Asia > Indonesia > articles > the-10-most-beautiful...

The places which this website offered are Dieng Plateau, Borobudur Temple, Komodo National Park, Raja Ampat, Mount Bromo, Ubud, Lake Toba, Tana Toraja, Tanjung Puting National Park, Derawan Islands, Bangka Belitung Islands, Wae Rebo Village, Lombok, Nusa Islands, Bukittinggi. Why are there only 15 most beautiful places? In our assumption, whether those places are recognized by International visitors or those places have a good tourism development strategy.

This article discusses the place, which is probably still untouchable by International visitors, yet they have potential culture stories to sell to attract more visitors both domestic and international tourists to come to this place. The previous research concerning the tourist destination categorized as natural reservation, which is similar to this article, was conducted by Kamil and Abdullah (Kamil \& Abdoellah, 2018). In their research, they suggested that environmental awareness should be socialized to the community in order to preserve the conservation areas. They conducted their research in Kamojang as one of the tourist destinations in Garut West Java. They used communication strategy as their theoretical approach. According to their research, communication strategies should be planned by nature lover's communication forums. The communication strategy includes strategic planning, managerial planning, and operational planning. Tourism is a prospective industry, so it needs professional handling. In other research Tan Yang Teng, et al. tried to investigate whether there was a causal relationship between tourism, gross domestic product (GDP), and CO2 emission in Malaysia in the period of 1980 to 2014. By using a quantitative study, they used three variables from 1980 to 2014, the result showed that all three variables had a one-way direction of causality. Through the result, they concluded that tourism affected GDP at the same time affected CO2 (Teng et al., 2018). The negative externalities of CO2 emissions need to be minimized by enforcing the law and regulations published by the Malaysian Government.

Another study observed the development and expansion of adventure tourism. Their research was intended to make a proof of the adventure tourism which could offer not only daring journeys but also profitable business tourism industry (Alwi, Aziz, \& Mariappan, 2018). This adventure tourism could raise the impact on the local community whether to the culture, to the economy, or social.

The next research was conducted by having an interview with the local people. The aim of the interview was to investigate which impact caused much to the local people (Majid, Said, Basrah, \& Rahim, 2019). Based on the theory, there are four general impacts, in Ab. Majid, et al. study, the general impacts were born into twenty-six elements. Those twenty-six elements were derived from interviewing 200 respondents. Their study came up to the result that twentyone out of twenty-six elements were correlated with the community demographic profile. Among the four elements, the element of culture mostly gave an impact to the local community.

Other research was conducted using A'WOT (AHP-SWOT) hybrid method (Kisii, 2019). This method is a combination of SWOT (Strengths, Weaknesses, Opportunities, Threats) analysis and the AHP (Analytic Hierarchy Process) method. The SWOT analysis was used to identify significant strategic factors, and the AHP method was applied to prioritize these strategic 
factors. His study shows the results that the dependent economic structure may have defected with the development of the tourism industry and, therefore, that some strategic initiatives are required to achieve sustainable tourism.

Based on the previous research, it shows that the tourism industry expands so fast and varied, as the consequences, this industry is supposed to be fully considered and perfected in its field of inquiry (Ateljevic, Pritchard, \& Morgan, 2007). There are various tourist destinations that offer the adventure or daring journey and the local culture to the tourists. Offering the story or the legend of the local culture is quite promising in the tourism business industry. Kuningan offers the legend of "Kancra Bodas" fish or "God" Fish as the intention not only to attract tourists but also maintain the local value of both the local community and the environment.

Regarding the location, Kuningan, Royyani and Syukur (Royyani \& Syukur, 2013) conducted their research in two villages in Kuningan. They observed the traditional ritual of Kawin Cai (Water Marriage) by using the anthropological approach. Kawin cai is one of the traditional rituals in Kuningan society. The existence of Kawin Cai traditional ritual is to promote the local wisdom to the youngest. Similar to the study conducted by Royyani and Syukur, this study also tries to promote the local wisdom in Cibulan as one of the sustainable development tourism strategies.

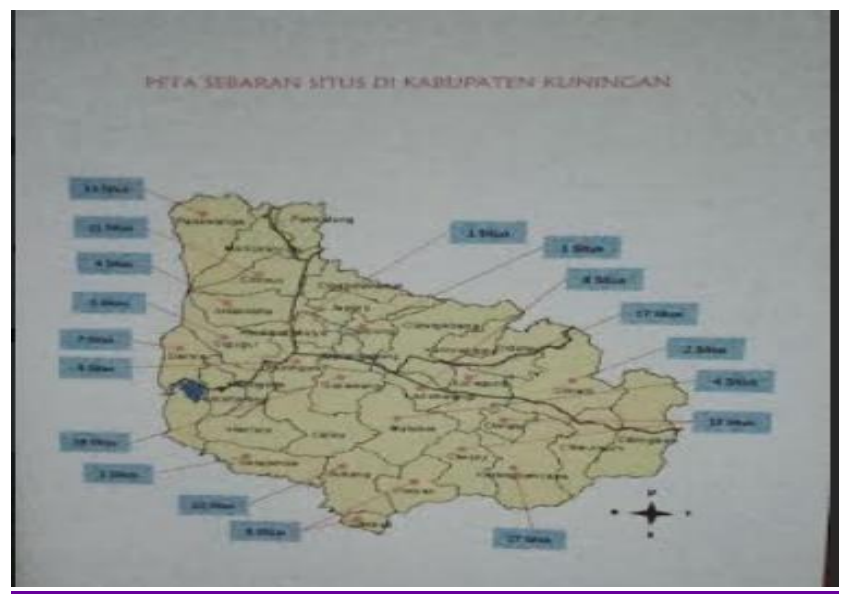

Picture 1. Sites Map in Kuningan District

Kuningan consists of 18 districts. Cibulan is located in Jalaksana district, Maniskidul village office. Based on information in book guidance published by Kuningan district local Government - Education and Culture Service, in Kuningan there are 143 sites consisting of ancient graveyards, statues, and legendary waterfalls.

Cibulan is one of the tourist destinations located about $7 \mathrm{~km}$ from the center of Kuningan. In this destination, visitors could go swimming along with the fish. Swimming with fish is one effort to attract more visitors to come. There are two swimming pools built in 5 hectares consisting of two big pools sized $35 \times 15$ square meters with depth about 2 meters, while the second pools sized $45 \times 15$ square meters divided into two pools with a depth of $60 \mathrm{~cm}$ and 120 cm each.

The uniqueness of those pools is the containment of Kancra bodas fish (Labeobarbus Dournesis) or well-known as God-fish. These fish are benign, people could go swimming along with fish. Furthermore, it is believed that if people could touch this fish they will have been blessed by God. Visitors could swim and touch the fish, but they cannot take the fish out of the 
pool to be consumed. Local people believe if they take the fish out of the pool they will be cursed or get into an accident.

Another story said that the amount of God-fish either decreases or increases. There are none of them even count the amount of fish, but this is a kind of belief of local people. It is deduced that the faith of the local people to the story legend of Prabu Siliwangi and also the existence of God-fish offers new benefits and new perspectives to the tourism industry in especially Kuningan district. The prohibition of not taking the fish out of the pool and prohibited to consume by people teach the local people to maintain the existence of fish ecology in this area.

However, there is one research conducted in the area that reports about the extinction of Godfish (Abidin, Marwoto, \& Iswari, 2018). Their research was conducted using physical and chemical parameters. According to their findings, the extinction of God-fish started in 2006. They tried to find out the factors of the extinction of those God-fish. Their research results showed that the factors of the extinction were the condition of water quality and the condition of substrate, not to mention the plentifulness of variety and consistency of zooplankton correlated positively with $\mathrm{pH}$, temperature, $\mathrm{DO}$ and water flow.

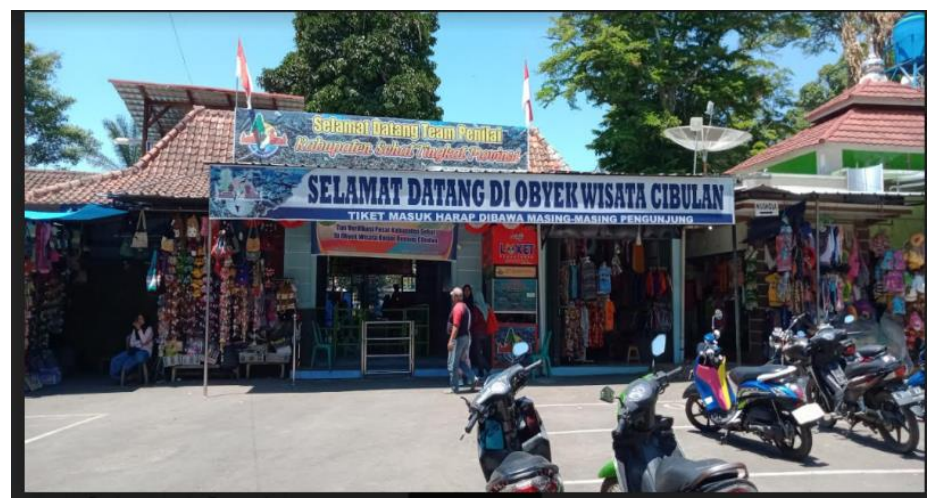

Picture 2. The Gate of Cibulan Tourist Destination

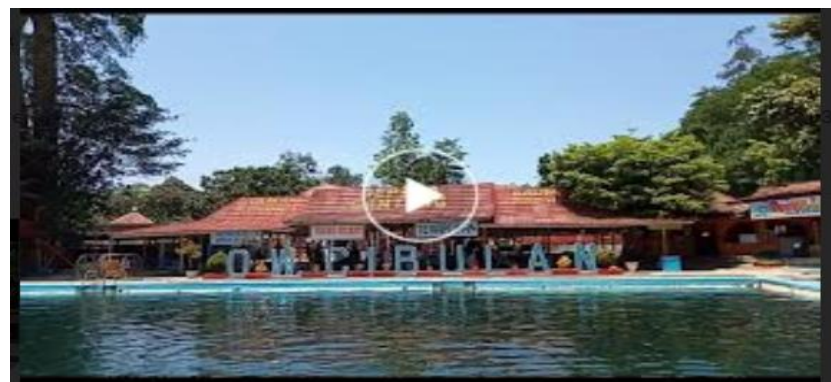

Picture 3. Cibulan's Swimming Pool Contains the God-Fish

The tourism department in Kuningan tries its best to compete in National tourism. This effort has not only positive but also a negative side. The positive side is that this effort has good impact to the income of people in Kuningan, on the other hand, the old people tend to be worried that this tourism development strategy would destroy the ecosystem and ecological lives of the environment as in line with the research result conducted by Abidin et al. (2018). It is not only the legend of Kancra bodas fish or well-known as God-fish gives a good insight for tourism industries in order to sustain the ecological system, but also it needs the participation from local people to maintain the ecosystem in order to prevent the God-fish from 
extinction. These findings are in accord with the concept of sustainability in tourism (https://kuninganmass.com $>$ business $>$ tourism $>$ object).

\section{Literature Review}

\section{The Concept of Sustainability}

The term sustainability is still evolving, especially in the tourism sector both internal and external. Why is it so difficult to define the terminology of sustainability? According to Mowforth and Munt (2016) the different meanings of sustainability terminology are caused by different perspectives between individuals, organizations and social groups (Mowforth \& Munt, 2016). The corporations have different interpretations of sustainability from those of communities and activists. From the corporation's point of view, sustainability still concerns controlling the customer's buying habits. This sustainability is a kind of buying a product that is based on their concern for the environment. Meanwhile, communities and activists strongly argue against the concept of sustainability proposed by corporations. They are suspicious that this corporation hides something behind the concept of sustainability. So that is why they struggle to resist the destruction of the countryside (Mowforth and Munt, 2016).

Furthermore, Mowforth and Munt (2016) also had difficulties in defining the word sustainability. According to them, the term sustainability containing a contested concept i.e. a concept constructed both socially and politically in which it shows the attentiveness and values for those involved. Mowforth and Munt try to explain the meaning of sustainability in a broader context. Based on Mowforth and Munt understanding how to define the word sustainability depends on different ideas in which this word is used, whether sustain advantage in the tourism industry, sustain used by social classes to preserve particular holidays, or sustain used by 'host' communities in order to deny access to outsiders.

Other interpretations of sustainability are still contrasted between environmentalists and industrialists. To environmentalists sustainability concerns of natural resources, the necessity to maintain and keep the safe natural environment, while to the industrialists the meaning of sustainability is the chance to get bigger financial gain, to make less of costs, gain customers and keep hold of market share (see Mowforth and Munt, 2016: 6). The World Bank and the International Monetary Fund (IMF) have their own perspectives on the representation of tourism and sustainability. They have keen different opinions from local communities in the countries in which the law of local government should be put in (Mowforth and Munt, 2016: 7).

\section{Sustainability in Tourism}

Based on the theorists, there are three notions that are fundamental to the analysis of new tourism: globalization, sustainability and development (Mowforth and Munt, 2016: 48). The inequitable nature of general capitalist growth had been taken into a sharp discussion (Allen and Massey, 1995; Daniels et al., 2001; Smith, 1989) and eventually deduced that globalization and sustainability are concurrent universalistic discussion (Mowforth and Munt, 2016: 34).

According to Rist, the source of sustainability derived from the Western craze for ecology and environmental matters (Rist, 2008). The term sustainability is also interpreted in economic, cultural and social fields. In line with Rist, Mowforth and Munt (2016) also believe that "sustainability is a crucial part of the ideology of the New World Order and all the trends and tendencies that are associated with it." In addition, the term 'sustainability' in the field of tourism has been taken over by many sides in order to give moral goodness and qualification 
to tourist activities. The practice of tourism bears new forms of tourism and sustainable tourism has spread all over the world as an attractive tourist destination.

Mowforth and Munt (2016) proposed the criteria of which was often used for sustainability in tourism; there are four types of sustainability in tourism, i.e. cultural, social, environmental, and economic sustainability. Those four types of sustainability need education, the participation of locals, and the aid to conservation. Based on Mowforth and Munt (2016) the term of social sustainability is a kind of the ability of community whether local or national to absorb or adapt the inputs without generating social frictions as the consequences of those inputs. The understanding of cultural sustainability is the ability of people to preserve or adapt their culture's elements which distinguish them from other people. Even Though the societies are able to continue functioning in social harmony, the interaction between the local people and tourists are unavoidable. That interaction could cause to the cultural impact. However, the cultural impacts will be seen over the long term, so that it is difficult to measure. The term economic sustainability goes to economic gain from tourism activities to cover the cost of any special measures and to reduce the impact on the local community due to the presence of the visitors.

\section{Folklore and Legend}

Legend is part of folklore. There are various forms of folklore such as myths, folktales, legends, folk songs, proverbs, riddles, games, dances and many others. In this subsection, we should discuss the understanding between folklore and legend since they are inseparable. We cannot understand legend unless we view folklore in a particular way.

One folklorist suggests that folklore should be taught by teachers to students so teachers understand their students better and by teaching folklore students would understand the world and human condition (Bronner, 2007). According to Dundes folklore is the crucial method in which cultural knowledge and wisdom are transferred from generation to generation and from peer to peer (in Bronner, 2007). Furthermore, Dundes believes that folklore could develop tolerance and students could learn their own cultural traditions.

Based on Dundes's opinion children's folklore is not something to be kept but rather to make into the public. Since folklore is a kind of people's reflection or people's own description. Dundes also described the difficult situation during the African, American and Vietnamese Civil Rights movement and the Vietnam war into folklore. He tried to explain using the alternative answers whenever he described the presence of the Cold War into the riddle joke of "what's black and white and red all over?" Dundes also argued that the conflict that emerged in the Cold War was due to "ethnic and international tension grounded in cultural misunderstanding." So, Dundes hoped that by teaching folklore, teachers would give the best insight into cultural understanding for their students.

Dundes's career as folklorist proposed the principles of the modern concept of folklore. In Dundes's opinion, folklore should be constantly created "a new contemporary life". He said that "it is not a relic of the past, as many people believe, but an expression of present-day issues." According to Dundes, there should be a need for cross-cultural research as the purpose is to form international folkloristics. He also objected to the tendency of dividing folklore into national categories. In his opinion, it might lead to difficulties in declaring that traditions belong to distinctive and unique locations. 
Based on the argumentation of Dundes, it is understood that folklore holds the key to the local wisdom in which this local wisdom should be passed on from generation to generation. By learning folklore, it is hoped that the next generations have a good insight into their native story and knowing them as part of their mother's or native cultures. Folklore is the way people describe themselves and bring out the evidence through legend. Legend is the story that is supported by physical evidence. Such as the legend of God-fish in Cibulan, Kuningan, West Java, Indonesia.

In the Study of American Folklore (1968), it is said that folklore has its own characteristics such as (1) it is oral; (2) it is traditional; (3) it exists in different versions; (4) it is usually anonymous; (5) it tends to become formularized (Hutomo, 1991). The concept of folklore are the following (1) oral literature; (2) written literature source from the local community; (3) cultural expression included (a) cultural technology; (b) people's knowledge; (c) art and recreation (Hutomo, 1991: 8)

Legend, according to some scholars, refers to historical events that happened in the past. So, some people believe that legend is 'people's histories' (Hutomo, 1991: 64). According to Bascom (1965) legend is a story that is similar to myth but is not considered as sacred (in Hutomo, 1991). The actor in legend usually was an ordinary man, but he had an extraordinary character, quite often this actor had been helped by something which was not visible (ghost). The event took place on earth which had been recognized up to now (not on the other world) and it happened not quite long ago.

\section{Results of Research and Discussion}

The research was conducted in 2019. the researchers did the observation and interview with the informants. the informants were the village official and the keeper of the tomb. the data used in this research consists of primary and secondary. primary data were derived directly in the field of research while the secondary data were derived from the documents and the works of literature.

Previous research was conducted from April until July 2019 by Putri et al. (2019). they used the quantitative method to analyze the effectiveness of the God-Fish Legend In Kuningan as the effort to preserve the existence of god-fish. based on the spearman correlation statistical test, the result showed that there was a positive correlation between the story legend ( $\mathrm{x}$ variable) and the sustainable behavior ( $y$ variable) with the value of correlation coefficient $=0.264$. this recent study tries to continue to observe and identify how the god-fish legend may raise the sustainable tourism development strategy. this study did not use the quantitative method, this research uses the qualitative study instead.

Based on the previous study results, it confirms that there is a positive correlation between godfish legend and sustainable behavior. this result is in line with the principles of sustainability in tourism, i.e. cultural, social, environmental, and economic sustainability. as a result, the government should continue to strengthen the legend as an attractive tourist destination. in addition, the ecosystem of god-fish should also be the main focus since they offer not only the people's legend story but also the value of indigenous locals in which it should be obeyed by the next generation and by the visitors.

According to the data from the sports and tourism youth services in Kuningan, there are about 45 tourist destinations in Kuningan. the number of visitors who came to Cibulan during 2017, 2018, and 2019 was 105.918; 90.742; and 79.568 respectively. the data of the number of 
visitors and the places that were visited by the tourists around 2017 (table 1), 2018 (table 2), and 2019 (table 3) are described below.

\section{Table 1. The Data of Visitors to Tourist Destinations in Kuningan District 2017}

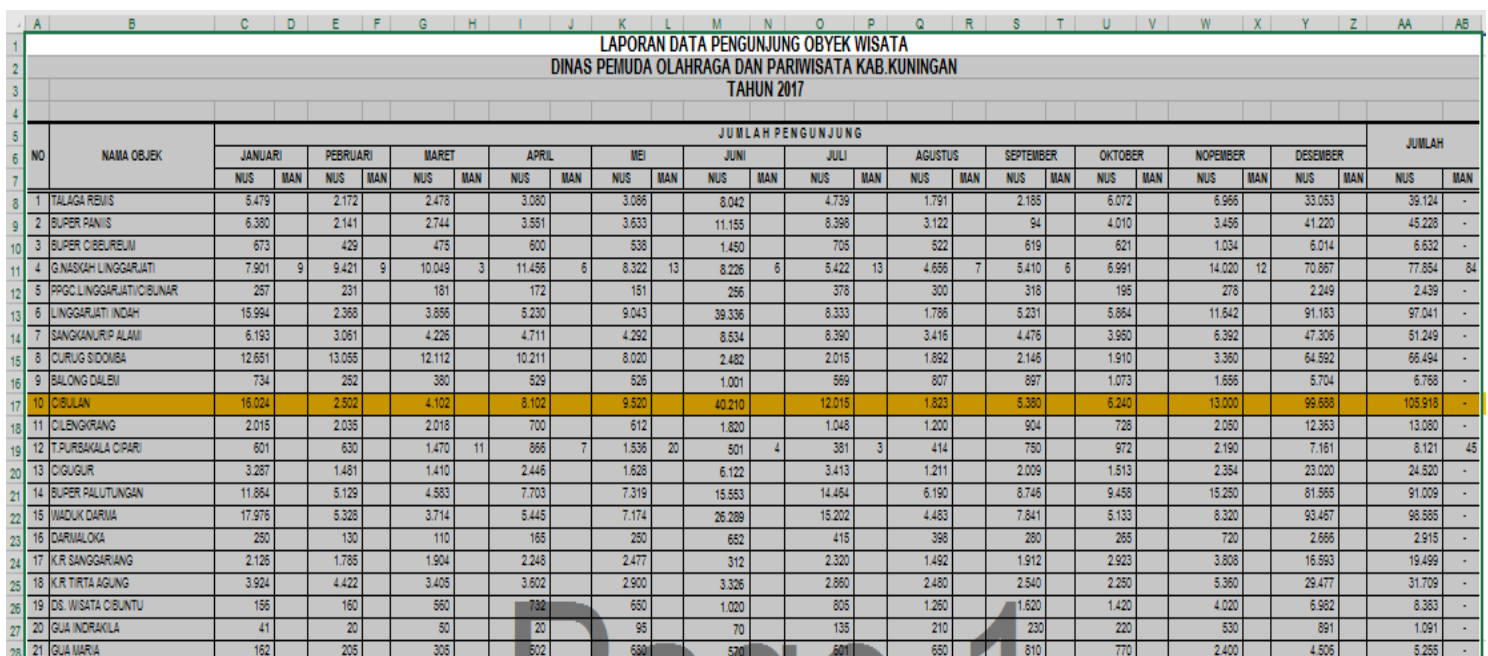

Source: The Sports and Tourism Youth Services in Kuningan, 2017

Based on table 1 above, it can be seen that the number of visitors who came to Cibulan was 105.918. It took place as the most visited tourist destination in Kuningan. The second place was Curug Landung with 102.612 visitors. However, mostly the tourists were from the domestic ones.

Table 2. The Data of Visitors to Tourist Destinations in Kuningan District 2018

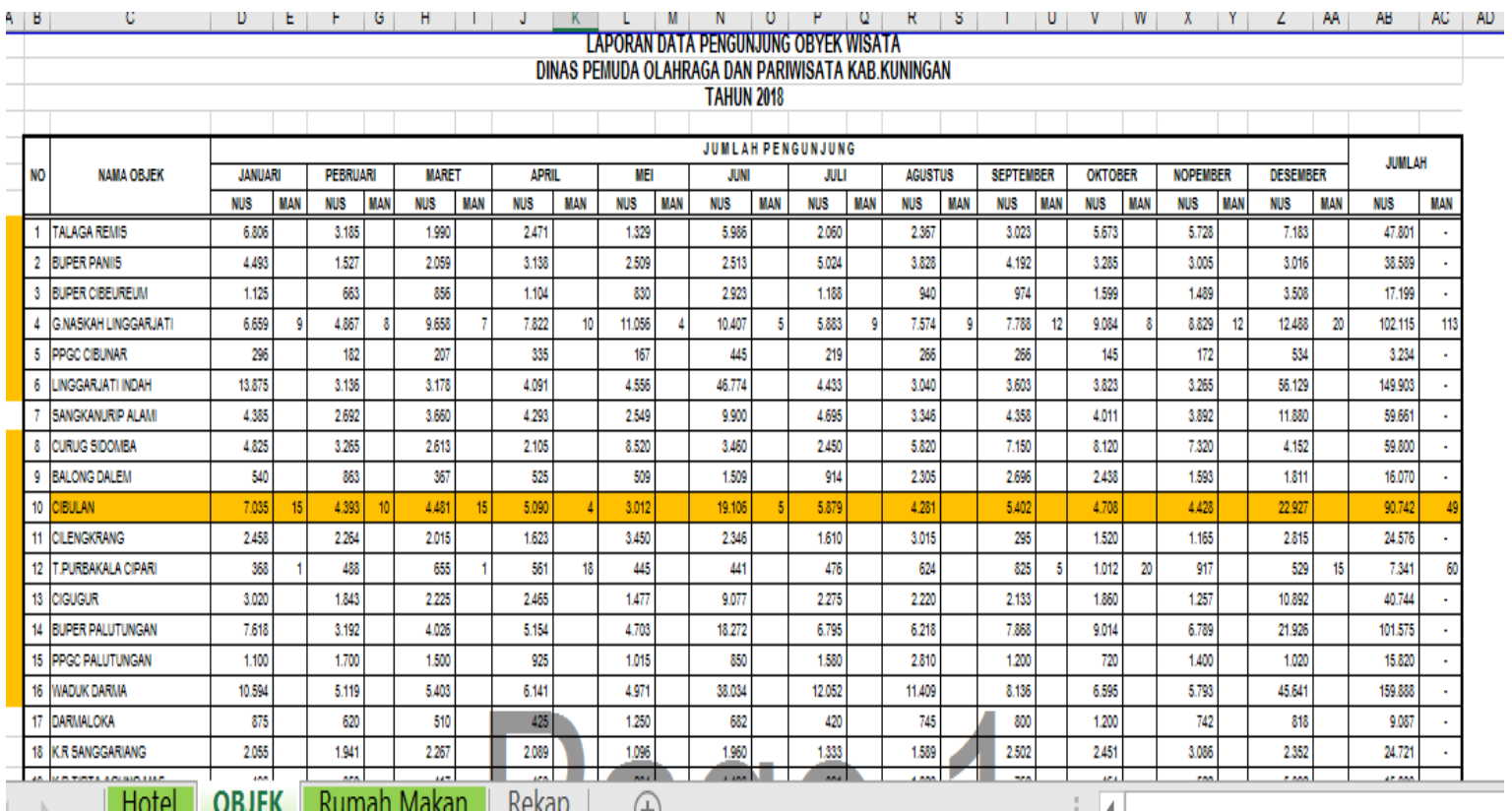

Source: The Sports and Tourism Youth Services in Kuningan, 2018

Compared to the number of visitors to Cibulan in 2017, in 2018 the number of visitors was decreasing around $0,85 \%$. There were about 90.472 who came to Cibulan. Even Though the number of domestic tourists was decreasing, the number of foreign visitors was seemingly turning out to be promising. It was recorded that they were 49 foreign visitors who came to 
Cibulan. However, the researchers hadn't got a chance to do a survey in order to find out the reason why they chose Cibulan as their destination.

Table 3. The Data of Visitors to Tourist Destination in Kuningan District 2019

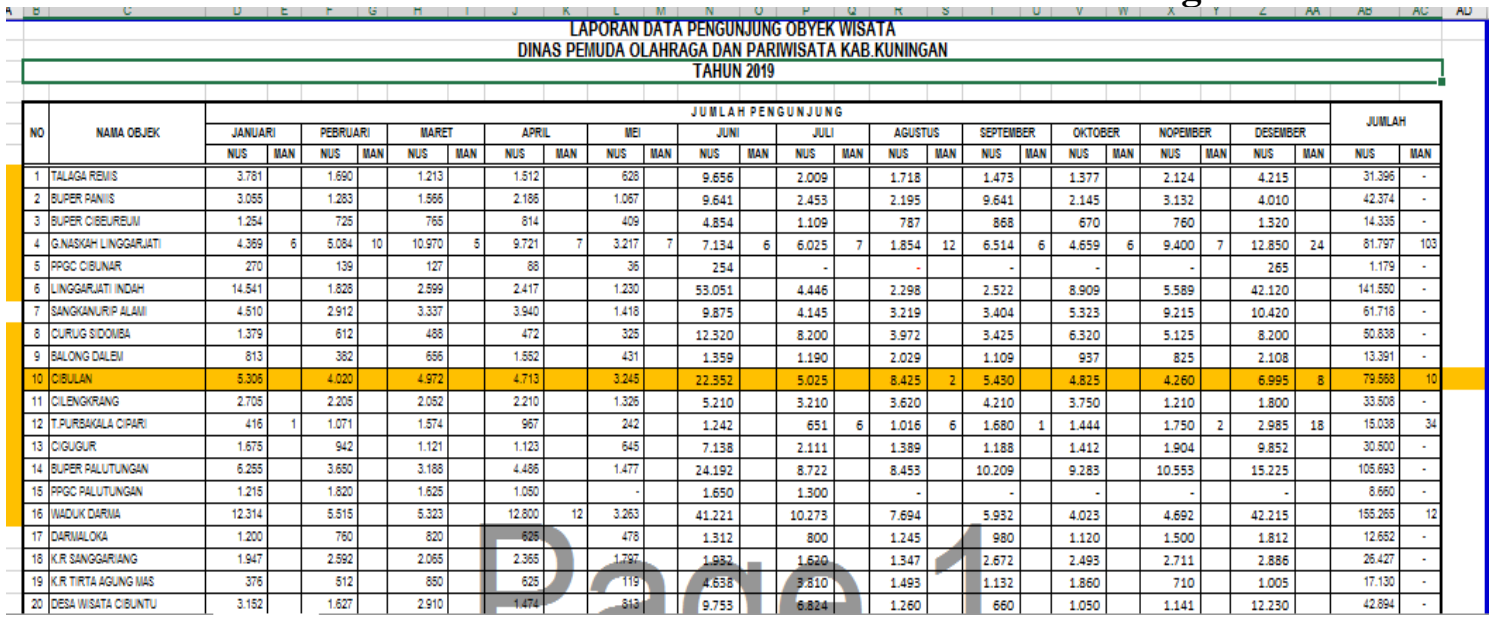

Source: The Sports and Tourism Youth Services in Kuningan, 2018

In table 3 , it can be seen that the number of visitors was decreased about $0,87 \%$. The domestic tourists were decreasing to 79.568 . The number of foreign visitors was decreasing drastically around $20 \%$. There were recorded only 10 foreign visitors who came to Cibulan.

From those tables above, the decreasing number of visitors needs to be investigated. The local government has revitalized the infrastructure of this tourist destination, still they need the strategy to promote the legend of Kancra bodas fish or well-known as God-fish as the tourist object.

To conclude, this Kancra bodas fish legend is considered as the continuation of economic development for the local people; globalization is not reflected in the numbers of foreign tourists visiting this place. However, this tourist destination fits into a source of sustainability which consists of ecology and environmental matters. It is also along with the theory of sustainability consisting of economic, cultural, and social fields. The district government has tried their best effort to promote the local story through the Education and Culture Services in the Cultural Department by publishing a book namely "Warisan Tempo Dulu (Fakta dan Data Situs-situs Kabupaten Kuningan)". This book contains the heritage sites in Kuningan. In order to reach globalization, there is an infelicitous nature of general capitalist growth. The district government so far, has tried to get into the development of tourist destinations, however it needs professional hands to build this tourist destination in order to promote this place. In addition, economic development seems to grow so slowly. The local tour guides need to be trained how to inform the tourists both local and foreign about this place and the Government should handle the revenue. So that there will be mutualism symbiosis both for the local tour guides and the local trader.

\section{Conclusion}

The legend of Kancra bodas fish or well-known as God-fish is the effort of Indonesian local government to maintain the existence of God-fish as the sustainable tourism development strategies. Offering the story legend as one of the tourist destinations also will attract more visitors to come. Through the story legend there are four important factors which will be beneficial for Cibulan tourist destination, that is the increasing numbers of visitors, maintaining Copyright $\odot$ C GLOBAL ACADEMIC EXCELLENCE (M) SDN BHD - All rights reserved 
the existence of God-fish, teach the younger or next generation and visitors to learn and practice the local wisdom into their daily lives and also pass down this story legend to the next generation so this story legend still persists in the society whether inside or outside Kuningan society. However, it needs a professional hand to assist the growth of monthly income for local tour guides and local traders.

\section{References}

Ab Majid, R., Said, R., Basrah, N., \& Rahim, N. A. (2019). The Impact of Rural Tourism on The Local Community Development. Journal of Tourism, Hospitality and Management Development, 39-55.

Abidin, Z., Marwoto, P., \& Iswari, R. S. (2018). The influence of physical and chemical parameters on the extinction of the god fish (Tor douronensis) species: a case study in Balong Dalem Kuningan district. International Conference on Mathematics, Science and Education 2017 (ICMSE2017) (p. 1-6). Open Access: IOP Conf. Series: Journal of Physics: Conf. Series 983 (2018) 012201.

Allen, J. a. (1995). Geographical Worlds. Milton Keynes: Open University Press.

Alwi, M. K., Aziz, A., \& Mariappan, M. (2018). From Risky Endeavors to Profitable Ventures: An Overview of the Development and Expansion of Adventure Tourism. Journal of Tourism, Hospitality, and Environment Management, 64-75.

Bascom, W. K. (1965). The Form of Folklore: Prose Narratives. Journal of American Folklore, 3-20.

Butterworth-Heinemann. (2006). Sustainable Tourism. Theory and Practice. Oxford: Elsevier Ltd.

Daniels, P., Bradshaw, M., Shaw, D., \& Sidaway, a. J. (2001). Human Geography: Issues for the 21st Century. Harlow, UK: Prentice-Hall.

Development, W. C. (1987). Our Common Future. New York: United Nations.

Hutomo, S. S. (1991). Mutiara yang Terlupakan. Pengantar Studi Sastra Lisan. Jawa Timur: Himpunan Sarjana Kesusastraan Indonesia (HISKI).

Kamil, I., \& Abdullah, O. S. (2018). Role of Environmental Communities in Kamojang Natural Java Natural Reservation. Journal of Tourism, Hospitality, and Environment Management, 46-53.

Kisi, N. (13 February 2019). A Strategic Approach to Sustainable Tourism Development Using the A'WOT Hybrid Method: A Case Study of Zonguldak, Turkey. International Journal of Sustainability 11, 964, 1-19.

Mowforth, Martin \& Munt, Ian. (2016). Tourism and Sustainability. Development, Globalisation, and New Tourism in the Third World. New York: Routledge.

Pritchard, N., \& Morgan, A. (2007). De-centring Tourism's Intellectual Universe or Traversing the Dialogue Between Change and Tradition. Dalam I. Ateljevic, A. Pritchard, \& a. N. Morgan, The Critical Terms in Tourism Studies. Innovative Research Methodologies (p. 11). Amsterdam: Elsevier.

Putri, D. A., Ahmad, F., \& Indah, E. (2019). Efektivitas Keberadaan Cerita Rakyat Kuningan terhadap Kelestarian Ikan Dewa: Laporan Akhir Program Kreativitas Mahasiswa. Bogor: Institut Pertanian Bogor.

Rist, G. (2008). History of Development. London: Zed Books.

Royyani, M. F., \& Syukur, A. (December 2013). Traditional Ritual Water Conservation and Islamic Thought. Heritage of Nusantara. International Journal of Religious Literature and Heritage. Vol 2. No. 2, 117-144.

Smith, V. (1989). Hosts and Guests: The Anthropology of Tourism. Philadelphia, PA: University of Pennsylvania Press. 
Teng, T. Y., Yeap, A., Yi, C. R., Shyuan, L. C., Jing, T. W., \& Xin, Y. Y. (2018). Tourism, Economic Growth, CO2 Emissions: The case of Malaysia. Journal of Tourism, Hospitality, and Environment Management; vol 3 issues 12, 01-10. 